\title{
Blood Lead Level in Relation to Awareness and Self Reported Symptoms among Gasoline Station Workers in the Gaza Strip
}

\author{
MAGED M. YASSIN,${ }^{1}$ ABDEL MONEM H. LUBBAD ${ }^{2}$
}

\begin{abstract}
Background: Leaded gasoline is being used in Gaza Strip. Measurements of blood lead level (BLL) and relate it to awareness of gasoline station workers would be helpful in lead protection programs.

Purpose: To determine BLL and to assess its relation to awareness and self reported symptoms among gasoline station workers in the Gaza Strip.

Methods: A cross section of 72 workers was asked to fill in a questionnaire. BLL was determined by atomic absorption spectrometry.

Results: Thirty four (47.2\%) workers had BLL>10 $\mu \mathrm{g} / \mathrm{dl}$. The mean BLL was inversely related to the education level $(p=0.001)$. Workers worked d" 5 years in the station had lower BLL than those worked $>5$ years $(7.8 \pm 5.6 \vee 12.5 \pm 5.8 \mu \mathrm{g} / \mathrm{dl}, p=0.004)$. The variation in workers' knowledge by their BLL was not significant. Higher BLL was generally found in workers who did not practice protective measures compared to those who did, with significant difference for respiratory mask $(I 2.4 \pm 5.9 \vee 5.6 \pm I .6 \mu \mathrm{g} / \mathrm{dl}, p=0.00 I)$, gloves $(I 3 . I \pm 6.0 \vee 8.6 \pm 4.9 \mu \mathrm{g} / \mathrm{dl}, p=0.00 I)$ and frequent milk drink $(I 3.5 \pm 6.0 \vee 9.3 \pm 5.2 \mu \mathrm{g} / \mathrm{dl}, p=0.018)$. Higher BLL was also found in workers who reported symptoms than in those who did not, with significant differences for irritability $(I 2.4 \pm 5.4 \vee 9.2 \pm 5.6 \mu \mathrm{g} / \mathrm{dl}, p=0.03 \mathrm{I})$, headache $(I 2.2 \pm 5.8 \vee 9.0 \pm 5.9 \mu \mathrm{g} /$ dl, $p=0.046)$, concentration difficulties ( $12.9 \pm 5.8 \vee 9.4 \pm 5.6 \mu \mathrm{g} / \mathrm{dl}, p=0.015)$, sleep disturbances $(I 4.1 \pm 5.8$ v $8.9 \pm 5.0 \mu \mathrm{g} / \mathrm{dl}, p=0.00 \mathrm{I})$ and hypertension $(\mathrm{I} 3.3 \pm 6.4 \vee 8.1 \pm 2.9 \mu \mathrm{g} / \mathrm{dl}, p=0.00 \mathrm{I})$.

Conclusions: High BLL was associated with low education level, long work duration, lack of protective measures and increase self reported symptoms. Educational programs on protective measures practices are recommended.
\end{abstract}

Key Words: Awareness; Blood lead level; Gasoline station workers; Gaza Strip; Symptoms.

\section{Introduction:}

Lead has a widespread application in general industry including lead-based paint, battery manufacture and reclamation, radiator repair, leaded gasoline and pottery/ ceramics. ${ }^{1-4}$ Leaded gasoline contains tetraethyllead and, to some extent, tetramethyllead which are used as "anti-knock" additives to gasoline. ${ }^{5}$ Lead exposure in gasoline station occurs from lead fumes generated during filling cars, from cars emissions and from contaminated hands, food, water and clothing 6,7 .

As a fume or fine particulate, lead is readily absorbed through the lungs. It is relatively less well-absorbed from the gastrointestinal tract. Inorganic lead is not absorbed through intact skin, but organic lead compounds (tetraethyllead, tetramethyllead) can be. ${ }^{8}$ Once lead has been absorbed into the bloodstream, it is distributed between the bones and

1. Professor of Physiology at Faculty of Medicine, The Islamic University of Gaza, Gaza Strip Palestine.

2. Associate Professor of Pathology at Faculty of Medicine, The Islamic University of Gaza, Gaza Strip Palestine.

Correspondence: Prof. Maged M. Yassin, Professor of Physiology at Faculty of Medicine, The Islamic University of Gaza, Gaza Strip Palestine. E-mail: myassin@iugaza.edu.ps teeth, the soft tissues and the blood. ${ }^{9}$ Blood lead level was used as a direct indicator for lead exposure in gasoline station workers as well as an indication of potential for adverse effect on health ${ }^{10}$.

Research on occupational lead exposure have been shown that blood lead level was positively associated with eating lunch at work, duration of employment, lack of adequate respirators, uncommon and improper use of rubber boots and gloves, lack of training programs and lead poisoning awareness campaigns. ${ }^{11,12}$

The presence of lead in the human body can lead to toxic effects regardless of exposure pathway. Major symptoms of intoxication with leaded gasoline include headache, fatigue, irritability, impaired concentration, wrist/foot drop, nausea, dyspepsia, constipation, colic, lead line on gingival tissue, loss of libido and anemia. ${ }^{13-16}$

The present study was aimed to determine for the first time blood lead level in gasoline station workers and relate it to various aspects of awareness and self reported symptoms among them in the Gaza Strip. The specific objectives were to answer the following research questions: (1) Does blood lead level of gasoline station workers relate to their age, 
education, work duration and house location?; (2) what is the level of workers' knowledge on route of lead entry into the body, lead health effects and lead as an environmental pollutant?, and is there a relationship between BLL and such knowledge?; (3) Do workers have practices towards the protective measures?, and which of them relate to BLL?; (4) what are the self reported symptoms among workers?; and is there an association between BLL and such symptoms?

\section{Study area}

The Gaza Strip is a part of the Palestinian coastal plain bordered by Egypt from the South, the green line from the North, Nagev desert from the East and the Mediterranean Sea from the West. The total surface area of the Gaza Strip is $360 \mathrm{~km}^{2}$, where about 1.64 million Palestinian people live and work $^{17}$. The Gaza Strip is divided geographically into five Governorates: Northern, Gaza, Mid Zone, Khan Younis and Rafah.

Gaza Strip is a poor area suffering from a long-term pattern of economic stagnation and plummeting development indicators ${ }^{18}$. The situation becomes even worse since Israel imposed extreme restrictions on the movement of goods and people in response to the new political situation in the Gaza Strip. The unemployment rate in the Gaza Strip is $32.2 \% 19$.

The Gaza Strip suffers from many environmental problems including extensive use/misuse of pesticides, water pollution and lack of sewage and solid waste treatment ${ }^{20-22}$. Air pollution is another environmental burden in the Gaza Strip caused to a large extent by carbon monoxide, nitrogen oxide and lead emitted by petrol vehicles. Leaded gasoline imported from Israel and Egypt is still the predominant fuel grade in the Gaza Strip ${ }^{23,24}$. Lead emitted from such fuel imposes serious health problems on both general population and gasoline station workers in the Gaza Strip.

\section{Materials and methods:}

\section{Study design and target population}

This investigation was a cross sectional study. The target population was gasoline station workers in the five Governorates of the Gaza Strip during the spring of 2006. For ethical consideration, the necessary approval to conduct the study was obtained from Helsinki committee in the Gaza Strip in January, 2006.

\section{Sample size and sampling}

The estimated number of legal gasoline stations registered in the Gaza Strip in the year 2006 was 81 distributed in the five Governorates of the Gaza Strip as follows: Northern
(17), Gaza (27), Mid Zone (10), Khan Yunis (19) and Rafah (8). According to the municipalities of Gaza Governorates, Palestinian National Authority (Personal communication), the estimated total number of workers in Gaza Governorates was 208, distributed as follows: Northern (36), Gaza (77), Mid Zone (24), Khan Yunis (45), and Rafah (26). A stratified sample was used based on the formula:

No. of workers/Governorate $\mathrm{X}$ Sample size $=$ No. of required Total No. of workers workers/Governorate

Therefore, our sample size of 105 gasoline station workers was distributed according to the number of workers in each Governorate as follows: Northern (18), Gaza (39), Mid Zone (12), Khan Yunis (23), and Rafah (13). Out of the 105 workers, 72 freely gave blood samples for BLL analysis and answered a questionnaire questions i.e. the response rate was $68.6 \%$.

\section{Questionnaire interview}

A meeting interview was used for filling in the questionnaire. A total of 72 workers were questioned. All interviews were conducted face to face. The questionnaire was based on adult lead poisoning questionnaire with some modifications ${ }^{25}$. The questionnaire was validated by four specialists in the fields of environment and public health. Most questions were one of two types: the yes/no question, which offers a dichotomous choice; and the multiple choice question, which offers several fixed alternatives ${ }^{26}$. A questionnaire was piloted among 10 gasoline station workers not included in the sample, and modified as necessary for improving reliability. The questionnaire included questions related to: personal profile such as age and education; work duration; house location to other lead facility; and knowledge on the route of lead entry into the human body, health effects of leaded gasoline exposure and lead as an environmental pollutant. Practice questions included: the wearing of protective gear; smoking; drinking and eating during work; chewing gum; whether they drink milk frequently or not; and whether to have a water bath or not at work place. Selfreported symptoms questions were also included in the questionnaire.

\section{Determination of blood lead level}

Blood samples were collected from the median cubital vein by a well trained nurse. About $3 \mathrm{ml}$ blood was drawn from each worker by plastic metallic-free disposable syringe (SANWOO coroporation-Korea) into vacutainer vial containing potassium ethylenediamine tetracetic acid "EDTA (K3)" as anticoagulant produced by AFMA-DISPO-Jordan. Blood lead level was determined by atomic absorption spectrometry based on the method described by Miller and his colleagues ${ }^{27}$. Quantification was based on the 
measurement of light absorbed at $283.3 \mathrm{~nm}$ by ground state atoms of lead from either an electrode-less discharge lamp or from a hollow-cathode lamp source. Blood samples human and bovine blood quality control pools, and aqueous standards were diluted with a matrix modifier (nitric acid, Triton X - 100, and ammonium phosphate). The lead content was determined by using a Perkin-Elmer model 5100 atomic absorption spectrophotometer with Zeeman Effect background correction. Lead contamination was carefully avoided throughout all procedures.

\section{Data analysis}

Data were computer analyzed using SPSS/PC (Statistical Package for the Social Science Inc. Chicago, 1llinois USA, version 13.0) statistical package. Simple distribution of the study variables, the cross tabulation and the mean of the BLL were applied $^{28}$. The one-way ANOVA test was used for analysis of variance for average BLL as quantitative dependant variable by qualitative variables. The independent-sample t-test procedure was used to compare means of quantitative variables by the separated cases into two qualitative groups. The result was accepted as statistically significant when the p-value was less than 5\% $(\mathrm{p}<0.05)$.

\section{Results:}

Distribution of BLL among gasoline station workers $(n=72)$

The mean BLL of gasoline station workers was $11.4 \mu \mathrm{g} / \mathrm{dl}$ distributed as follows: 38 (52.8\%) workers had BLL $<10 \mu \mathrm{g} / \mathrm{dl}$ with mean of $6.8 \pm 1.5 \mu \mathrm{g} / \mathrm{dl}, 24(33.3 \%)$ workers had BLL10$19.9 \mu \mathrm{g} / \mathrm{dl}$ with mean of $14.1 \pm 2.5 \mu \mathrm{g} / \mathrm{dl}$ and $10(13.9 \%)$ workers had BLL 20-30 $\mu \mathrm{g} / \mathrm{dl}$ with mean of $22.6 \pm 2.4 \mu \mathrm{g} / \mathrm{dl}$ (Table I).

Table-I

Distribution of blood lead level among gasoline station workers $(n=72)$ in the Gaza Strip

\begin{tabular}{lcc}
\hline Blood lead level (?g/dl) & No. $(\%)$ & Mean $\pm \mathrm{SD}(? \mathrm{~g} / \mathrm{dl})$ \\
\hline$<10$ & $38(52.8)$ & $6.8 \pm 1.5$ \\
$10-19.9$ & $24(33.3)$ & $14.1 \pm 2.5$ \\
$20-30$ & $10(13.9)$ & $22.6 \pm 2.4$ \\
\hline
\end{tabular}

Blood lead level was expressed as mean $\pm \mathrm{SD}$

Blood lead level in relation to age and education of workers

As indicated in Table II, the highest mean BLL $(15.7 \pm 6.5 \mu \mathrm{g} /$ dl) was found in workers aged $>50$ years old whereas the lowest $(8.7 \pm 5.3 \mu \mathrm{g} / \mathrm{dl})$ was found in those aged $19-26$ years old. However, there was no significant relationship between BLL and age of the workers $(F=1.874, p=0.125)$. Analysis of the educational status of the workers $(n=72)$ showed that none of them was illiterate. The mean BLL decreased with increasing education level, where BLL of workers who had a university degree was $8.0 \pm 4.3 \mu \mathrm{g} / \mathrm{dl}$ and of those who had passed primary school it was $16.2 \pm 7.3 \mu \mathrm{g} / \mathrm{dl}$. This inverse relationship was statistically significant $(F=10.120, p=0.001)$.

Table-II

Blood lead level of gasoline station workers $(n=72)$ in relation to personal characters

\begin{tabular}{lcccc}
\hline Personal character & No. (\%) & $\begin{array}{c}\text { Mean } \pm \text { SD } \\
(\mu \mathrm{g} / \mathrm{dl})\end{array}$ & F & P-value \\
\hline Age (year) & $11(15.3)$ & $8.7 \pm 5.3$ & & \\
$19-26$ & $24(33.3)$ & $12.4 \pm 6.7$ & 1.874 & 0.125 \\
$27-34$ & $16(22.2$ & $9.9 \pm 4.2$ & & \\
$35-42$ & $15(20.8)$ & $11.8 \pm 5.8$ & & \\
$43-50$ & $6(8.3)$ & $15.7 \pm 6.5$ & & \\
$>50$ & & & & \\
Education & $22(30.6)$ & $16.2 \pm 7.3$ & & \\
Primary school & $12(16.7)$ & $10.8 \pm 3.8$ & & \\
Preparatory school & $29(40.3)$ & $9.1 \pm 3.4$ & & \\
Secondary school & $9(12.5)$ & $8.0 \pm 4.3$ & 10.120 & 0.001 \\
\hline University & & & \\
\hline
\end{tabular}

Blood lead level was expressed as mean $\pm \mathrm{SD}, \mathrm{P}<0.05$ : significant

\section{Blood lead level in relation to work duration}

As depicted from Table III, the mean BLL of workers who worked in the station for 1-5 years was significantly lower than that of workers who worked for $>5$ years $(7.8 \pm 5.6 v$ $12.5 \pm 5.8 \mu \mathrm{g} / \mathrm{dl}, \mathrm{t}=2.945, \mathrm{p}=0.004)$. It is worth mentioning that, all interviewed workers had no history of other lead-related job.

\section{Table-III}

Blood lead level of workers $(n=72)$ in relation to work duration

\begin{tabular}{llccc}
\hline $\begin{array}{l}\text { Work duration } \\
\text { (year) }\end{array}$ & No. $(\%)$ & $\begin{array}{c}\text { Mean } \pm \text { SD } \\
(\mu \mathrm{g} / \mathrm{dl})\end{array}$ & $\mathrm{t}$ & P-value \\
\hline $1-5$ & $16(22.2)$ & $7.8 \pm 5.6$ & 2.945 & 0.004 \\
$>5$ & $56(77.8)$ & $12.5 \pm 5.8$ & & \\
\hline
\end{tabular}

Blood lead level was expressed as mean $\pm \mathrm{SD}, \mathrm{P}<0.05$ : significant

\section{Blood lead level in relation to house location to other lead facility}

None of the workers was found to live near lead smelter (Table IV). In addition, there were no significant differences in the mean blood levels of workers in relation to house location to other lead facilities including battery workshop, auto radiator workshop and garage of cars $(\mathrm{p}>0.05)$. 
Table-IV

Blood lead level of gasoline station workers $(n=72)$ in relation to house location to other lead facility ( $>50$ meter)

\begin{tabular}{|c|c|c|c|c|}
\hline $\begin{array}{l}\text { House location } \\
\text { to lead facility }\end{array}$ & No. $(\%)$ & $\begin{array}{c}\text { Mean } \pm \text { SD } \\
(\mu \mathrm{g} / \mathrm{dl})\end{array}$ & $\mathrm{t}$ & P-value \\
\hline \multicolumn{5}{|l|}{ Lead smelter } \\
\hline Yes & $0(0.0)$ & 0.0 & NA* & $\mathrm{NA}^{*}$ \\
\hline No & $72(100)$ & $11.4 \pm 6.0$ & & \\
\hline \multicolumn{5}{|c|}{ Battery workshop } \\
\hline Yes & $4(5.6)$ & $9.0 \pm 1.8$ & 0.708 & 0.481 \\
\hline No & $68(94.4)$ & $11.5 \pm 6.1$ & & \\
\hline \multicolumn{5}{|c|}{ Auto radiator workshop } \\
\hline Yes & $3(4.2)$ & $10.0 \pm 0.7$ & 0.341 & 0.734 \\
\hline No & $69(95.8)$ & $11.5 \pm 6.0$ & & \\
\hline \multicolumn{5}{|l|}{ Garage of cars } \\
\hline Yes & $8(11.1)$ & $11.8 \pm 4.5$ & 0.209 & 0.835 \\
\hline No & $64(88.9)$ & $11.4 \pm 6.2$ & & \\
\hline
\end{tabular}

NA*: Non applicable, blood lead level was expressed as mean $\pm \mathrm{SD}$, $\mathrm{P}>0.05$ : non significant

Blood lead level in relation to workers' knowledge on route of lead entry into the body, health effects of leaded gasoline exposure and lead as an environmental pollutant

Table $\mathrm{V}$ revealed that a higher proportion of workers had knowledge on inhalation as a route of lead entry into the body $62(86.1 \%)$, health effects of leaded gasoline exposure $57(79.2 \%)$ and lead as an environmental pollutant $59(81.9 \%)$. On the other hand, a lower proportion of workers had knowledge on skin 21 $(29.2 \%)$ and mouth $18(25.0 \%)$ as routes of lead entry. However, the variation in such workers' knowledge by their BLLs was not significant $(\mathrm{p}>0.05)$.

\section{Table-V}

Blood lead level of gasoline station workers $(n=72)$ in relation to their knowledge on route of lead entry into the body, health effects of leaded gasoline exposure and lead as an environmental pollutant

\begin{tabular}{|c|c|c|c|c|}
\hline Knowledge on & No. $(\%)$ & $\begin{array}{c}\text { Mean } \pm \text { SD } \\
(\mu \mathrm{g} / \mathrm{dl})\end{array}$ & $\mathrm{t}$ & P-value \\
\hline \multicolumn{5}{|c|}{ Route of lead entry into body } \\
\hline \multicolumn{5}{|l|}{ Inhalation } \\
\hline Yes & $62(86.1)$ & $10.6 \pm 7.9$ & 0.469 & 0.640 \\
\hline No & $10(13.9)$ & $11.6 \pm 5.7$ & & \\
\hline \multicolumn{5}{|l|}{ Skin } \\
\hline Yes & $21(29.2)$ & $11.3 \pm 5.3$ & 0.113 & 0.910 \\
\hline No & $51(70.8)$ & $11.5 \pm 6.3$ & & \\
\hline \multicolumn{5}{|l|}{ Mouth } \\
\hline Yes & $18(25.0)$ & $13.0 \pm 6.0$ & 1.311 & 0.194 \\
\hline No & $54(75.0)$ & $10.9 \pm 5.9$ & & \\
\hline \multicolumn{5}{|c|}{ Health effects of leaded gasoline exposure } \\
\hline Yes & $57(79.2)$ & $12.1 \pm 5.8$ & 1.877 & 0.065 \\
\hline No & $15(20.8)$ & $8.9 \pm 6.1$ & & \\
\hline \multicolumn{5}{|c|}{ Lead as an environmental pollutant } \\
\hline Yes & $59(81.9)$ & $11.5 \pm 5.8$ & 0.098 & 0.922 \\
\hline No & $13(18.1)$ & $11.3 \pm 7.1$ & & \\
\hline
\end{tabular}

Blood lead level was expressed as mean $\pm \mathrm{SD}, \mathrm{P}>0.05$ : non significant

\section{Blood lead level in relation to protective gear in use}

As illustrated in Table VI, the protective gear was poorly used during work at the station where the highest number of workers $(n=27,37.5 \%)$ wore gloves and the lowest number $(n=4,5.6 \%)$ wore hats or special boots. In general, the mean BLL was found to be higher in workers who did not use protective gear than in those who did with significant differences for respiratory mask and gloves $(12.4 \pm 5.9 v$ $5.6 \pm 1.6 \mu \mathrm{g} / \mathrm{dl}, \mathrm{t}=3.609, \mathrm{p}=0.001$ and $13.1 \pm 6.0 v 8.6 \pm 4.9 \mu \mathrm{g} / \mathrm{dl}$, $\mathrm{t}=3.316, \mathrm{p}=0.001$, respectively).

\section{Table-VI}

Blood lead level of gasoline station workers $(n=72)$ in relation to protective gear in use

\begin{tabular}{lcccc}
\hline $\begin{array}{l}\text { Protective gear } \\
\text { in use }\end{array}$ & No. $(\%)$ & $\begin{array}{c}\text { Mean } \pm \text { SD } \\
(\mu \mathrm{g} / \mathrm{dl})\end{array}$ & $\mathrm{t}$ & P-value \\
\hline Yes & $27(37.5)$ & $8.6 \pm 4.9$ & 3.316 & 0.001 \\
No & $45(62.5)$ & $13.1 \pm 6.0$ & & \\
Wear goggles & & & & \\
Yes & $6(8.3)$ & $12.3 \pm 8.4$ & 0.376 & 0.708 \\
No & $66(91.7)$ & $11.7 \pm 5.9$ & & \\
Wear hat & & & & \\
Yes & $4(5.6)$ & $11.2 \pm 5.7$ & 0.038 & 0.970 \\
No & $68(94.4)$ & $11.4 \pm 6.0$ & &
\end{tabular}

Wear respiratory mask

$\begin{array}{lllll}\text { Yes } & 10(13.9) & 5.6 \pm 1.6 & & \\ \text { No } & 62(86.1) & 12.4 \pm 5.9 & 3.609 & 0.001\end{array}$

Wear special boots

$\begin{array}{ccccc}\text { Yes } & 4(5.6) & 7.9 \pm 2.8 & & \\ \text { No } & 68(94.4) & 11.0 \pm 6.0 & 0.661 & 0.511\end{array}$

Wear overall

\begin{tabular}{lllll} 
Yes & $12(16.7)$ & $11.4 \pm 5.6$ & & \\
No & $60(83.3)$ & $11.6 \pm 6.1$ & 0.084 & 0.933 \\
\hline
\end{tabular}

Blood lead level was expressed as mean $\pm \mathrm{SD}, \mathrm{P}>0.05$ : non significant, $\mathrm{P}<0.05$ : significant

\section{Blood lead level in relation to personal habits}

Table VII provides the personal habits of workers $(n=72)$ practiced at work place. The mean BLL of workers who were smoked, drunk, ate and chewed gum was higher than that of workers who were not. However, the difference was not significant $(p>0.05)$. The higher BLL was also found in workers who did not frequently drink milk, but the difference was significant $(13.5 \pm 6.0 v 9.3 \pm 5.2 \mu \mathrm{g} / \mathrm{dl}$, $\mathrm{t}=3.162, \mathrm{p}=0.018$ ). 
Table-VII

Blood lead level of gasoline station workers $(n=72)$ in relation to their personal habits

\begin{tabular}{|c|c|c|c|c|}
\hline Personal habit & No. $(\%)$ & $\begin{array}{c}\text { Mean } \pm \text { SD } \\
(\mu \mathrm{g} / \mathrm{dl})\end{array}$ & $\mathrm{t}$ & P-value \\
\hline \multicolumn{5}{|l|}{ Smoking } \\
\hline Yes & $34(47.2)$ & $12.8 \pm 6.3$ & 1.941 & 0.062 \\
\hline No & $38(52.8)$ & $10.2 \pm 5.5$ & & \\
\hline \multicolumn{5}{|l|}{ Drinking } \\
\hline Yes & $57(79.2)$ & $12.0 \pm 6.2$ & 1.528 & 0.131 \\
\hline No & $15(20.8)$ & $9.4 \pm 4.6$ & & \\
\hline \multicolumn{5}{|l|}{ Eating } \\
\hline Yes & $57(79.2)$ & $12.0 \pm 6.2$ & 1.640 & 0.105 \\
\hline No & $15(20.8)$ & $9.2 \pm 4.2$ & & \\
\hline \multicolumn{5}{|l|}{ Chewing gum } \\
\hline Yes & $8(11.1)$ & $11.9 \pm 5.5$ & 0.231 & 0.867 \\
\hline No & $64(88.9)$ & $11.4 \pm 6.1$ & & \\
\hline \multicolumn{5}{|c|}{ Frequently drink milk } \\
\hline Yes & $36(50.0)$ & $9.3 \pm 5.2$ & 3.162 & 0.018 \\
\hline No & $36(50.0)$ & $13.5 \pm 6.0$ & & \\
\hline \multicolumn{5}{|c|}{ Have water bath at work place } \\
\hline Yes & $9(12.5)$ & $13.1 \pm 7.2$ & 0.949 & 0.592 \\
\hline No & $63(87.5)$ & $11.6 \pm 5.8$ & & \\
\hline
\end{tabular}

Blood lead level was expressed as mean $\pm \mathrm{SD}, \mathrm{P}>0.05$ : non significant, $\mathrm{P}<0.05$ : significant

\section{Blood lead level in relation to self reported symptoms}

The recall period was shortened to three months preceding the interview to minimize the possibility of recall bias. Table VIII lists the prevalence of self reported symptoms among gasoline station workers $(\mathrm{n}=72)$, with headache being the most common $(\mathrm{n}=54,75.0 \%)$ and seizures and infertility were the least common $(n=3,4.2 \%)$. In general, the mean BLL was higher in workers who reported symptoms than in those who did not. However, the difference in the mean BLL was statistically significant for irritability $(12.4 \pm 5.4 v 9.2 \pm 5.6 \mu \mathrm{g} / \mathrm{dl}, \mathrm{t}=2.207, \mathrm{p}=0.031)$, headache $(12.2 \pm 5.8 \vee 9.0 \pm 5.9 \mu \mathrm{g} / \mathrm{dl}, \mathrm{t}=2.028, \mathrm{p}=0.046)$, concentration difficulties $(12.9 \pm 5.8 v 9.4 \pm 5.6 \mu \mathrm{g} / \mathrm{dl}, \mathrm{t}=2.501, \mathrm{p}=0.015)$, sleep disturbances $(14.1 \pm 5.8 v 8.9 \pm 5.0 \mu \mathrm{g} / \mathrm{dl}, \mathrm{t}=4.102, \mathrm{p}=0.001)$ and hypertension $(13.3 \pm 6.4 v 8.1 \pm 2.9 \mu \mathrm{g} / \mathrm{dl}, \mathrm{t}=3.912, \mathrm{p}=0.001)$.

\section{Table-VIII}

Blood lead level of gasoline station workers $(n=72)$ in relation to self reported symptoms

\begin{tabular}{lcccc}
\hline Personal habit & No. $(\%)$ & $\begin{array}{c}\text { Mean } \pm \text { SD } \\
(\mu \mathrm{g} / \mathrm{dl})\end{array}$ & $\mathrm{t}$ & P-value \\
\hline Fatigue & & & & \\
Yes & $53(73.6)$ & $12.2 \pm 5.6$ & 1.876 & 0.065 \\
No & $19(26.4)$ & $9.3 \pm 6.6$ & & \\
Irritability & & & & \\
Yes & $50(69.4)$ & $12.4 \pm 5.4$ & 2.207 & 0.031 \\
No & $22(30.6)$ & $9.2 \pm 5.6$ & & \\
\hline
\end{tabular}

table continued

\begin{tabular}{|c|c|c|c|c|}
\hline $\begin{array}{l}\text { Coma } \\
\text { Yes } \\
\text { No }\end{array}$ & $\begin{array}{c}5(6.9) \\
67(93.1)\end{array}$ & $\begin{array}{c}8.8 \pm 6.1 \\
11.6 \pm 1.9\end{array}$ & 0.897 & 0.373 \\
\hline $\begin{array}{l}\text { Convt } \\
\text { Yes } \\
\text { No }\end{array}$ & $\begin{array}{c}4(5.6) \\
68(94.4)\end{array}$ & $\begin{array}{l}11.7 \pm 3.8 \\
11.4 \pm 6.1\end{array}$ & 0.081 & 0.936 \\
\hline $\begin{array}{l}\text { Heada } \\
\text { Yes } \\
\text { No }\end{array}$ & $\begin{array}{l}54(75.0) \\
18(25.0)\end{array}$ & $\begin{array}{c}12.2 \pm 5.8 \\
9.0 \pm 5.9\end{array}$ & 2.028 & 0.046 \\
\hline $\begin{array}{l}\text { Conce } \\
\text { Yes } \\
\text { No }\end{array}$ & $\begin{array}{l}\text { ifficulties } \\
42(58.3) \\
30(41.7)\end{array}$ & $\begin{array}{c}12.9 \pm 5.8 \\
9.4 \pm 5.6\end{array}$ & 2.501 & 0.015 \\
\hline $\begin{array}{l}\text { Sleep } \\
\text { Yes } \\
\text { No }\end{array}$ & $\begin{array}{l}\text { es } \\
35(48.6) \\
37(51.4)\end{array}$ & $\begin{array}{c}14.1 \pm 5.8 \\
8.9 \pm 5.0\end{array}$ & 4.102 & 0.001 \\
\hline $\begin{array}{l}\text { Seizur } \\
\text { Yes } \\
\text { No }\end{array}$ & $\begin{array}{c}3(4.2) \\
69(95.8)\end{array}$ & $\begin{array}{l}17.2 \pm 2.4 \\
11.3 \pm 5.9\end{array}$ & 1.148 & 0.255 \\
\hline $\begin{array}{l}\text { Hearir } \\
\text { Yes } \\
\text { No }\end{array}$ & $\begin{array}{l}17(23.6) \\
55(76.4)\end{array}$ & $\begin{array}{l}12.5 \pm 5.1 \\
11.1 \pm 6.2\end{array}$ & 0.831 & 0.409 \\
\hline $\begin{array}{l}\text { Wrist/ } \\
\text { Yes } \\
\text { No }\end{array}$ & $\begin{array}{l}28(38.9) \\
44(61.1)\end{array}$ & $\begin{array}{l}11.8 \pm 5.9 \\
11.2 \pm 6.7\end{array}$ & 0.456 & 0.65 \\
\hline $\begin{array}{l}\text { Loss o } \\
\text { Yes } \\
\text { No }\end{array}$ & $\begin{array}{l}27(37.5) \\
45(62.5)\end{array}$ & $\begin{array}{l}12.5 \pm 6.3 \\
10.8 \pm 5.8\end{array}$ & 1.181 & 0.242 \\
\hline $\begin{array}{l}\text { Nause } \\
\text { Yes } \\
\text { No }\end{array}$ & $\begin{array}{l}37(51.4) \\
35(48.6)\end{array}$ & $\begin{array}{l}11.0 \pm 6.1 \\
11.9 \pm 5.9\end{array}$ & 0.604 & 0.548 \\
\hline $\begin{array}{l}\text { Dyspe } \\
\text { Yes } \\
\text { No }\end{array}$ & $\begin{array}{l}29(40.3) \\
43(59.7)\end{array}$ & $\begin{array}{l}12.4 \pm 6.4 \\
10.7 \pm 5.6\end{array}$ & 1.188 & 0.239 \\
\hline $\begin{array}{l}\text { Const } \\
\text { Yes } \\
\text { No }\end{array}$ & $\begin{array}{l}30(41.7) \\
42(58.3)\end{array}$ & $\begin{array}{l}12.2 \pm 5.6 \\
10.9 \pm 6.2\end{array}$ & 0.944 & 0.348 \\
\hline $\begin{array}{l}\text { Abdon } \\
\text { Yes } \\
\text { No }\end{array}$ & $\begin{array}{l}25(34.7) \\
47(65.3)\end{array}$ & $\begin{array}{l}12.3 \pm 6.4 \\
11.0 \pm 5.7\end{array}$ & 0.895 & 0.374 \\
\hline $\begin{array}{l}\text { Lead li } \\
\text { Yes } \\
\text { No }\end{array}$ & $\begin{array}{l}\text { ival tissue } \\
11(15.3) \\
61(84.7)\end{array}$ & $\begin{array}{l}12.5 \pm 6.5 \\
11.2 \pm 5.9\end{array}$ & 0.631 & 0.53 \\
\hline $\begin{array}{l}\text { Renal } \\
\text { Yes } \\
\text { No }\end{array}$ & $\begin{array}{l}11(15.3) \\
61(84.7)\end{array}$ & $\begin{array}{l}13.5 \pm 5.4 \\
11.1 \pm 6.0\end{array}$ & 1.26 & 0.212 \\
\hline $\begin{array}{l}\text { Hyper } \\
\text { Yes } \\
\text { No }\end{array}$ & $\begin{array}{l}46(63.9) \\
26(36.1)\end{array}$ & $\begin{array}{c}13.3 \pm 6.4 \\
8.1 \pm 2.9\end{array}$ & 3.912 & 0.001 \\
\hline $\begin{array}{l}\text { Inferti } \\
\text { Yes } \\
\text { No }\end{array}$ & $\begin{array}{c}3(4.2) \\
69(95.8)\end{array}$ & $\begin{array}{l}18.4 \pm 2.1 \\
11.3 \pm 5.9\end{array}$ & 1.888 & 0.063 \\
\hline
\end{tabular}

Blood lead level was expressed as mean $\pm \mathrm{SD}, \mathrm{P}>0.05$ : non significant, $\mathrm{P}<0.05$ : significant 


\section{Discussion:}

Although leaded gasoline is still the predominant fuel grade in the Gaza Strip, no previous research have been determined BLL in gasoline station workers and relate it to their awareness and self reported symptoms. Blood lead level is the most widely used measure and powerful indicator for occupationally lead exposure. Several authors used BLL as a direct indicator for lead exposure in gasoline station workers as well as an indication of potential for adverse effect on health. ${ }^{10,29}$

The mean BLL of gasoline station workers recorded in the present study $(11.4 \mu \mathrm{g} / \mathrm{dl})$ was higher than that reported in Denmark, Ghana, and in Athens, where mean BLLs were 3.5, 8.6 and $5.6 \mu \mathrm{g} / \mathrm{dl}$, respectively. ${ }^{30-32}$ The higher BLL recorded in Gaza Strip workers may be attributed to poor use of protective measures and lack of awareness programs,${ }^{15}$ which implemented in other countries. In Greater Beirut even higher mean BLL $(18.4 \mu \mathrm{g} / \mathrm{dl})$ was found compared to Gaza workers ${ }^{29}$, which was attributed to frequent sniffing of cars in such traffic busy city.

The result that none of the workers found to be illiterate do reflect a well educated community. Such finding may give the impression that the high rate of educated workers is a result of them not getting another job because of the unemployment crisis in the Gaza Strip. ${ }^{18}$ The level of education was inversely related to BLL of workers i.e. the higher educational level of the workers, the lower BLL they had. This means that the more educated workers were more aware of the risk of lead exposure. Similar result was obtained in lead workers in Taiwan. ${ }^{33}$

Regarding work duration, the finding that more than two thirds of the workers worked in the gasoline station for more than 5 years, and all workers had no history of other lead-related job may imply that most of lead exposure coming from the workplace. The insignificant differences in mean BLLs of workers in relation to their houses location to other lead facilities probably support this view. The mean BLL was significantly increased with increased work duration at the station. This positive association more likely put workers health at a higher risk. Lead toxicity was more frequently encountered with longer term occupational lead exposure. ${ }^{34}$

The finding that a higher proportion of gasoline station workers were more aware of inhalational of leaded gasoline than other routes of exposure agrees with other studies which have found that most occupational exposure to lead occur through inhalation. ${ }^{14,35}$ The high level of workers' knowledge on the health effects of leaded gasoline exposure was previously reported ${ }^{15}$. When BLL was related to workers' knowledge, no significant association was found. This implies that knowledge on lead hazards alone may be not enough to significantly decrease BLL among workers. It was indicated that lead awareness knowledge doesn't necessarily guarantee positive behavior change. ${ }^{36}$ Knowledge of lead hazards together with good hygiene and education of correct work practice may be the preferential way to reduce lead exposure $^{12,37}$.

The protective gear was poorly used. In general, the mean BLL was higher in workers who did not use protective gears than in those who did, with significant difference only for respiratory mask and gloves. The protective effect of respiratory mask and gloves against lead exposure do confirm that inhalation and hand contamination are important routes of lead exposure in gasoline station. Increasing of BLL was found in occupational lead workers who neglected protective measures including face masks ${ }^{38}$. Personal protective equipment was consider as an essential component in any occupational health and safety program and as a mean of preventing occupational lead absorption. ${ }^{39}$

The mean BLL was not significantly associated with the personal habits of workers except for drinking milk, where BLL was significantly higher in workers who did not frequently drink milk. It was reported that milk drinking by workers who occupationally exposed to lead reduced BLL. ${ }^{40}$ The degree of lead absorption is increased in person, whose diet is deficient in calcium, since calcium competes with lead for intestinal absorption ${ }^{41}$. Thus, the milk consumption is recommended as a dietary supplement for lead exposed workers in Gaza Strip to minimize lead absorption.

Regarding self reported symptoms, the mean BLL was generally higher in workers who reported symptoms than in those who did not with significant difference for irritability, headache, concentration difficulties, sleep disturbance and hypertension. This coincides with the idea that the nervous system is the primary target of lead toxicity. ${ }^{42}$ Such finding necessitates urgent prevention, intervention, and protection from the Ministry of Health and other non-governmental organizations. It was reported that workers with high BLL have a higher prevalence of most of the symptoms of lead toxicity than did workers with lower BLL in many countries including the neighboring ones. ${ }^{43}$

\section{Conclusion:}

Gasoline station workers in the Gaza Strip are still exposed to leaded gasoline. The mean BLL increased significantly in 
less educated and longer work duration-engaged workers. The variation in workers' knowledge on route of lead entry into the body, and its health and environmental effects by their BLLs was not significant. Use of protective measures was poor. Higher BLL was found in workers who did not practice protective measures with significant difference for respiratory mask, gloves and frequent milk drink. In general, higher BLL was also found in workers who reported symptoms than in those who did not with significant difference for irritability, headache, concentration difficulties, sleep disturbance and hypertension. Prevention and intervention programs regarding the use of protective measures and monitoring the health status of gasoline station workers should be implemented.

Conflict of interest: The authors have no relevant conflicts of interest to declare.

\section{References:}

1. Gonzalez-Soto E, Gonzalez-Rodriguez V, Lopez-Suarez C, Castro-Romero JM, Perez-Iglesias J, Fernandez-Solis JM. Migration of lead and cadmium from ceramic materials used in food preparation. Bull Environ Contam Toxicol 2000; 65: 598-603.

2. Hashisho Z, El-Fadel M. Impacts of traffic-induced lead emissions on air, soil and blood lead levels in Beirut. Environ Monit Assess 2004; 93: 185-202.

3. Clark CS, Rampal KG, Thuppil V, Roda SM, Succop P, Menrath W, et al. Lead levels in new enamel household paints from Asia, Africa and South America. Environ Res 2009; 109: 930-936.

4. Zhang Q. The current status on the recycling of lead-acid batteries in China. Int J Electrochem Sci 2013; 8: 6457-6466.

5. Royal Society of Chemistry. Health concerns of heavy metals and metalloids. Environmental Chemistry Group Bulletin 2012; 23-28.

6. Agency for Toxic Substance and Disease Registry. Case studies in environmental medicine: lead toxicity. U.S. Department of Health and Human Services 2000.

7. O'Brien E, Roberts A. Lead poisoning and climate change. Lead Action News 2009; 9: 1-29.

8. Papanikolaou NC, Hatzidaki EG, Belivanis S, Tzanakakis GN, Tsatsakis AM. Lead toxicity update. A brief review. Med Sci Monit 2005; 11: RA 329-RA336.

9. Crinnion WJ. EDTA redistribution of lead and cadmium into the soft tissues in a human with a high lead burden - should DMSA always be used to follow EDTA in such cases? Altern Med Rev 2011; 16 (2):109-112.

10. Al-Rudainy LA. Blood lead level among fuel station workers. Oman Med J 2010; 25 (3): 208-211.
11. Mortada WI, Sobh MA, El-Defrawy MM, Farahat SE. Study of lead exposure from automobile exhaust as a risk of nephro-toxicity among traffic policman. Am J Nephrol 2001; 21 (4): 274-279.

12. Rodrigues EG, Virji MA, McClean MD, Weinberg J, Woskie S, Pepper LD. Personal exposure, behavior, and work site conditions as determinants of blood lead among bridge painters. J Occup Environ Hyg 2010; 7 (2): 80-87.

13. Kuruvilla A, Pillay VV, Adhikari P, Venkatesh T, Chakrapani M, Rao HT, et al. Clinical manifestations of lead workers of Mangalore, India. Toxicol Ind Health 2006; 22: 405-413.

14. Mudipalli A. Lead hepatotoxicity and potential health effects. Indian J Med Res 2007; 126: 518-527.

15. Yassin MM, Baroud NS. Knowledge, attitude, practice and self reported symptoms among gasoline station workers exposed to leaded gasoline in the Gaza Strip. TJPH 2009; 7: 9-22.

16. Thuppil V, Tannir S. Treating lead toxicity: Possibilities beyond synthetic chelation. JKIMSU 2013; 2 (1): 4-31.

17. Palestinian Central Bureau of Statistics. Total Population of Palestinian Territory Mid 2012. Palestinian National Authority, 2012.

18. Giacaman R, Khatib R, Shabaneh L, Ramlawi A, Sabri B, Sabatinelli G, et al. Health status and health services in the occupied Palestinian territory. Lancet 2009; 373: 837-849.

19. Palestinian Central Bureau of Statistics. Labor Force Survey. Palestinian National Authority, 2013.

20. Yassin MM, Abu Mourad TA, Safi JM. Knowledge, attitude, practice and toxicity symptoms associated with pesticide use among farm workers in the Gaza Strip. Occup Environ Med 2002; 59: 387-393.

21. Yassin MM, Abu Amr SS, Al-Najar HM. Assessment of microbiological water quality and its relation to human health in Gaza Governorate, Gaza Strip. Public Health 2006; 120: 1177-1187.

22. Yassin MM, Tubail KM, Al-Dadah JY. Towards strategies for pollution control on the use of wastewater effluent in sustainable agriculture in the Gaza Strip. WRSTSD 2008; 5: 66-78.

23. Foner HA. Some aspects of lead pollution in Israel. Isr Environ Bull Summer 1999; 15.

24. United Nations Environment Programme. The global campaign to eliminate leaded gasoline: progress as of January, 2007.

25. Oregon Lead Poisoning Prevention Program, Adult Lead Poisoning Questionnaire (Patient Confidential Information), $\mathrm{I}: \backslash \mathrm{LP} \backslash \mathrm{ABLES} \backslash$ Forms $\backslash$ Adult Lead Questinnaire_2.doc DHS 44-3, (Updated 2008). Available from: http://www.governor. 
state.or.us/DHS/ph/lead/ docs/AdultPatient Questoinnaire.pdf

26. Backestrom C, Hursh-Cesar G. Survey research, Pennsylvania, United States: Literary Licensing, LLC, 2012.

27. Miller DT, Paschal DC, Gunter EW, Stroud PE, D’ Angelo J. Determinations of blood lead with elecrothermal atomic absorption using a L'vov platform and matrix modifier. Analyst 1987; 55: 712A-724A.

28. Kuzma JW. Basic statistics for the health sciences, 5th ed. USA: MCGRAW-HILL Higher Education, 2005.

29. Nuwayhid I, McPhaul K, Bu-Khuzam R, Duh SH, Christenson RH, Keogh JP. Determinants of elevated blood lead levels among working men in Greater Beirut. J Med Liban 2001; 49: 132-139.

30. Nielsen JB, Grandjean P, Jørgensen PJ. Blood lead concentration in the Danish population after introduction of lead-free gasoline. Ugeskr Laeger 1998; 160 (33): 4768-4771.

31. Ankrah NA, Kamiya Y, Appiah-Opong R, Akyeampon YA, Addae MM. Lead levels and related biochemical findings occurring in Ghanaian subjects occupationally exposed to lead. East Afr Med J 1996; 73 (6): 375-379.

32. Kapaki EN, Varelas PN, Syrigou AI, Spanaki MV, Andreadou E, Kakami AE, et al. Blood lead levels of traffic- and gasolineexposed professionals in the city of Athens. Arch Environ Health 1998; 53 (4): 287-291.

33. Chuang HY, Lee ML, Chao KY, Wang JD, Hu H. Relationship of blood lead levels to personal hygiene habits in lead battery workers: Taiwan, 1991-1997. Am J Ind Med 1999; 35 (6): 595-603.

34. Stoleski S, Karadzinska-Bislimovska J, Stikova E, RisteskaKuc S, Mijakoski D, Minov J. Adverse effects in workers exposed to inorganic lead. Arh Hig Rada Toksikol 2008; 59: $19-29$.
35. Pourmand A, Al-tiae TK, Mazer-Amirshahi M. Perspective on lead toxicity, a comparison between the United States and Iran. DARU Journal of Pharmaceutical Sciences 2012; 20:70.

36. Serwint JR, Dias M, White J. Effects of lead counseling for children with lead level e" $20 \mu \mathrm{g} / \mathrm{dl}$ : impact on parental knowledge, attitude and behavior. Clin Pediatr 2000; 39 (11): 643-650.

37. Lai JS, Wu TN, Liou SH, Shen CY, Guu CF, Ko KN, et al. A study of the relationship between ambient lead and blood lead among battery workers. Int Arch Occup Environ Health 1997; 9 (4): 295-300.

38. Willi RF, Felgenhauer N, Eyer F, Buters JT, Zilker T. Lead intoxication in a group of workers in Germany. Dtsch Med Wochenschr 2009; 134: 2556-2560.

39. Blayney MB. The need for empirically derived permeation data for personal protective equipment: the death of Dr. Karen E. Wetherhahn Appl Occup Environ Hyg 2001; 16 (2): 233236.

40. Wang VS, Lee MT, Chiou JY, Guu CF, Wu TN, Lai JS. Relationship between blood lead levels and renal function in lead battery workers. Int Arch Occup Environ Health 2002; 75 (8): 569-579.

41. Kristal-Boreh E, Froom P, Yerushalmi N, Ashkanazi R, Pardo A, Shine R, et al. Effect of dietary calcium on blood lead concentrations in occupationally exposed and nonexposed workers. Am J Ind Med 1998; 34 (5): 512-516.

42. Nemsadze K, Sanikidze T, Ratiani L, Gabunia L, Sharashenidze T. Mechanisms of lead-induced poisoning. Georgian Med News 2009; 172-173: 92-96.

43. Bener A, Almehdi AM, Alwash R, Al-Neamy FR. A pilot survey of BLL in various types of workers in the united of Emirates. Environ Int 2001; 27 (4): 311-314. 